\title{
Anthropogenic Food Utilization and Seasonal Difference in Diet of Cercopithecus lowei at a Community Protected Forest in Ghana
}

\author{
Godfred Bempah ${ }^{1}$, Changhu Lu ${ }^{2} \mathbb{D}$ and Yoonjung Yi ${ }^{3,4, * \mathbb{D}}$ \\ 1 College of Forestry, Nanjing Forestry University, Nanjing 210037, China; bempahgodfred@yahoo.com \\ 2 College of Biology and the Environment, Nanjing Forestry University, Nanjing 210037, China; \\ luchanghu@njfu.com.cn \\ 3 Laboratory of Animal Behaviour and Conservation, College of Biology and the Environment, Nanjing \\ Forestry University, Nanjing 210037, China \\ 4 Division of EcoScience, Ewha Womans University, Seoul 03760, Korea \\ * Correspondence: yi.yoonjung@gmail.com; Tel.: +86-152-5249-0435
}

check for updates

Citation: Bempah, G.; Lu, C.; Yi, Y. Anthropogenic Food Utilization and Seasonal Difference in Diet of Cercopithecus lowei at a Community Protected Forest in Ghana. Diversity 2021, 13, 610. https://doi.org/ 10.3390/d13120610

Academic Editor: Michael Wink

Received: 27 September 2021 Accepted: 18 November 2021 Published: 24 November 2021

Publisher's Note: MDPI stays neutral with regard to jurisdictional claims in published maps and institutional affiliations.

Copyright: (c) 2021 by the authors. Licensee MDPI, Basel, Switzerland. This article is an open access article distributed under the terms and conditions of the Creative Commons Attribution (CC BY) license (https:// creativecommons.org/licenses/by/ $4.0 /)$.

\begin{abstract}
In recent times, the diet and foraging behaviors of wild animals are influenced by anthropogenic foods since they often share their natural habitats with humans. We investigated the composition, preferred food item, contribution of anthropogenic food at garbage dump sites, and the seasonal effects on the diet of Lowe's monkeys (Cercopithecus lowei) in the Duasidan Monkey Sanctuary, Ghana. We found that Lowe's monkeys fed on 13 plant species, as well as anthropogenic foods and invertebrates. The composition of plant diet changed seasonally: Lowe's monkeys relied more on buds in the dry season while they consumed more fruits in the wet season. However, anthropogenic food was a major component of the diet for both wet (34.8\%) and dry seasons (41.3\%), suggesting that the monkeys consistently rely on anthropogenic food throughout the year. Nevertheless, we did not observe any conflict between monkeys and local people. The results suggest that Lowe's monkeys heavily rely on anthropogenic food at human garbage dumps while they maintain a part of their foraging activities in the wild, indicating a need for the proper management of garbage as well as the protection of the natural habitats of Lowe's monkeys in the Duasidan Monkey Sanctuary, Ghana.
\end{abstract}

Keywords: anthropogenic food; Cercopithecus; food availability; human settlement; Lowe's monkey

\section{Introduction}

The seasonal fluctuation of food resources can influence the foraging behavior or diet of animals [1]. For example, animals can shift their diet to alternative food resources available or increase time spent feeding or traveling [2,3]. Many wild animals inevitably share their habitat with humans, which can easily change their diet to incorporate human foods because of the abundant and constant supply [4]. The impacts of uncontrolled garbage dumps in and around forested areas are becoming critical since an increase in human population has caused human settlements to expand around ecosystems [5]. Many primates are reported to alter their diets towards available and accessible garbage deposits around human settlements [6-9].

Anthropogenic food can often present high risk to wildlife by causing health problems through increased exposure to pathogens and bacterial diseases [10,11]. For example, feeding on garbage may infect the wildlife with trichina worms (Trichinella spiralis) and fish tapeworms (Diphyllobothrium spp.) as well as leptospira bacteria [12-14]. Furthermore, in some vultures and condors, human-mediated food consumption was found to be related to chick mortality, probably because of indigestible elements [15]. In addition, wildlife with an energy-rich anthropogenic diet were found to have a smaller range, had a shorter distance of dispersal, and adjusted their general behaviors including foraging, travelling, and socializing $[8,16]$. 
Although we cannot ignore the negative impact of garbage, if managed properly, anthropogenic food can offer additional nutrients for wild animals (i.e., fallback food), resulting in increased weights and survival rates, decreased infant mortality, and, ultimately, increased population size [17-22]. For example, in Ursus americanus (American black bear), individuals that fed on anthropogenic foods grew and matured more rapidly, gained more weight, and developed a more robust reproductive system than individuals that solely relied on plant foods [23]. When wild animals are already heavily dependent on anthropogenic food, totally removing the anthropogenic food may negatively affect their survival and may increase human-animal conflict due to animals seeking food in humaninhabited areas. Thus, a proper management of the accessible anthropogenic food should be prioritized [21,23].

The Lowe's monkey (Cercopithecus lowei) is endemic to the upper Guinea rainforest and it is classified as vulnerable by the IUCN Red list [24] as its population size is decreasing due to habitat loss and degradation because of agriculture and human settlements [24]. The species is not exclusively arboreal and is mostly found close to ground cover in most forest types, including secondary forests, but not in marshy areas $[25,26]$. In Ghana, the species is found in a few protected areas including the Kakum Conservation Area [27] and Duasidan Monkey Sanctuary. In Duasidan, local people protect the Lowe's monkeys, following their traditional cultural belief. However, the monkeys in the area rely on anthropogenic foods. The main diet of Lowe's monkeys consists of fruits; however, they also feed on a wide range of plant parts including seeds, leaves, and buds [25]. Lowe's monkeys are generally understudied and the seasonal variation in the consumption of both natural and anthropogenic food is not known for the species. In this study, we examined the diet of Lowe monkeys, emphasizing the seasonal foraging activity and preference for wild foods as well as the utilization of anthropogenic food at the Duasidan Monkey Sanctuary in Ghana. During the dry season, humidity is very low, causing insufficient water availability for plant physiological processes and resulting in insufficient food quantity and quality [28,29]. Biodiversity monitoring conducted at the Duasidan monkey sanctuary reported that food quality and quantity was low during the dry season [30]. This may compel many animals to move out of their abode to access alternative foods [31]. We expected the diets and preferred food of the Lowe's monkeys to show seasonal variations because food is less commonly available in the dry season [30] and the anthropogenic foods function as an important food resource when natural food availability is low. Our study therefore aimed to (1) determine food categories consumed by Lowe's monkeys in the sanctuary and their seasonal variations, (2) identify preferred plants and plant parts consumed and their seasonal variations, and (3) provide information on the seasonal use of anthropogenic food as a food source by Lowe's monkeys.

\section{Materials and Methods}

\subsection{Study Area}

The study site, the Duasidan Monkey Sanctuary (DMS), is a good example of a natural habitat of Lowe's monkeys, situated near a human-dominated settlement. It is a community protected forest, about 1.8 ha in size, located on the outskirts of the Duasidan community $\left(7.2408^{\circ} \mathrm{N} ; 3.1144^{\circ} \mathrm{W}\right.$, Figure 1$)$. The vegetation consists of small pockets of riverine forest with many woody and herbaceous plants consisting of vines and climbers [30]. The terrain is quite flat with the main Duasidan stream bordering the extreme end of the sanctuary. The sanctuary lies in a zone that experiences bimodal rainfall, reaching about $1015 \mathrm{~mm}$ per year, typically accompanied by a wet season (April-October) and a dry season (November-March). Rainfall is the lowest in January, with an average of $17 \mathrm{~mm}$, and highest in September, with an average of $143 \mathrm{~mm}$. The area has a tropical climate, with mean minimum temperatures of $21^{\circ} \mathrm{C}$ and maximum temperatures of $26.8^{\circ} \mathrm{C}$. The local people in the community are predominantly farmers prioritizing food crops such as maize, cassava, plantain, and tree crops including cocoa and cashew. The people in the community dump garbage that is usually regular household (food and plastic) garbage at 
the fringes of the sanctuary. In this area, killing or causing harm to the monkeys is taboo and people and the monkeys have been mingling peacefully at the study site for more than 120 years. A traditional setup, enacted local by-laws and taboos, enforced by the chiefs and community elders, is used for the conservation of primates as well as promotion of eco-tourism (personal observation).

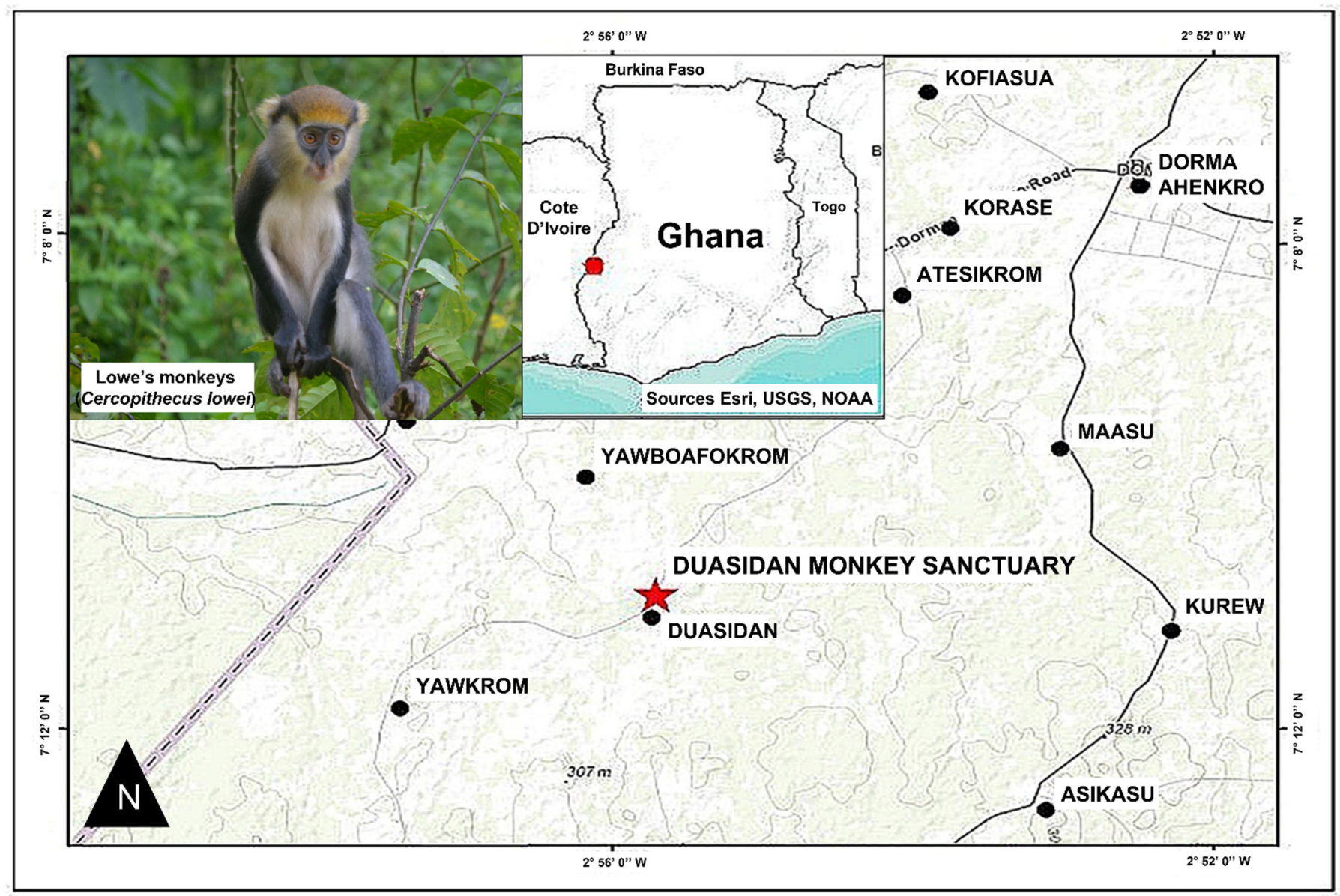

Figure 1. Location map of the study site, Duasidan Monkey Sanctuary (red star), Ghana and the study species, Lowe's monkeys (Cercopithecus lowei). Sources for the map: Esri, USGS, FAO, NPS, OpenStreetMap Contributors, and the GIS User community. Photo credit: Edward Debrah Wiafe.

\subsection{Data Collection}

We collected data by alternating among three Lowe's monkey groups with each group consisting of 8-15 individuals (including adults and juveniles) between 06:00 a.m. and 06:00 p.m. during the wet season (June-July) and dry season (January-February) for eight days per month in 2017, which resulted in an average time of $9.75 \pm 0.12 \mathrm{~h}$ per day and a total of $312 \mathrm{~h}$. We kept a distance of about 10-15 m from the monkeys while following them to avoid disturbing the group and regularly scanned the group at 10-min intervals to observe the activities. We recorded the behaviors of the monkeys following these categories: feeding, moving (all activities that involve locomotion including walking, playing, running, and jumping) and resting (all activities that did not involve locomotion including grooming, lying, sitting, and sleeping). We recorded the behavior of the majority of monkeys as a representative of the behavior at that time (e.g., $90 \%$ of individuals foraging is recorded as foraging), while trying to detect as many individuals as possible. We used predetermined forest trails of lengths of $50 \mathrm{~m}$ during the observations.

Food items eaten by the monkeys were classified into plants, anthropogenic food, and invertebrates. We recorded the feeding activities of the monkeys through instantaneous scan samples at 10-min intervals. At each scan period, we recorded the food items of 
the feeding individuals. We categorized plant food items into leaf, seed, fruit, flower, and bud. Furthermore, anthropogenic food was categorized into uncooked food/peel, leftover cooked food, and food in plastics (non-biodegradable materials/polythene bags). We assessed the presence of plant species in the Lowe's monkey habitat by randomly distributing six quadrats $(50 \times 50 \mathrm{~m})$ in the wet and dry seasons and calculated the relative abundance of food plant species [32-35]. The number of feeding visits to a plant species as well as parts consumed were recorded and used to calculate the preference indices of a plant species (total number of observations on a particular plant species consumed/relative abundance of the plant species) by the Lowe's monkeys.

\subsection{Data Analysis}

We used Wilcoxon rank sum tests to examine seasonal differences in diet composition (i.e., proportion of plants, anthropogenic foods, invertebrates in diet), plant type (i.e., proportion of fruits, flowers, leaves, seeds, buds in diet), and anthropogenic food types (i.e., proportion of uncooked food/peel, leftover cooked food, and food in plastics). We also used the Shannon-Wiener diversity index $(\mathrm{H})$ to calculate the diversity of plant species consumed by Lowe's monkeys and compared it between wet and dry seasons. To determine a preferred plant species, we calculated preference indices of plant species as total number of observations on a plant species consumed/relative abundance of that plant species in the six quadrats. We calculated the range of preference indices of a plant species and categorized them into three blocks: low (0-1.9), average (>1.9-3.9), and high (>3.9-6). We also ran a Wilcoxon rank sum test to examine seasonal difference in a preferred plant species. Statistical analyses were performed using $R$ ( $R$ version 4.0.3, $R$ core team 2020, Vienna, Austria).

\section{Results}

\subsection{Activity Budgets}

During the study period, the monkeys spent one-third of their time during the wet season feeding $(30.1 \% ; 57.8 \mathrm{~h})$ and two-fifths $(40.6 \% ; 77.9 \mathrm{~h})$ during the dry season. The monkeys spent two-fifths of their time during the wet season moving $(40.1 \% ; 76.9 \mathrm{~h})$ and two-fifths $(41.3 \% ; 79.3 \mathrm{~h})$ during the dry season. Finally, the monkeys spent one-third of their time during the wet season resting $(29.8 \% ; 57.2 \mathrm{~h})$ and one-sixth $(18.1 \% ; 34.8 \mathrm{~h}$, Figure 2) during the dry season. The monkeys spent significantly more time on feeding during the dry season than the wet season (Wilcoxon rank sum test; $\mathrm{N}=32, \mathrm{w}=256$, $p=0.0001)$ and significantly more time on resting during the wet season than the dry season (Wilcoxon rank sum test; $\mathrm{N}=32, \mathrm{w}=0, p=0.0001$ ). There was no significant difference in the amount of moving between both seasons $(\mathrm{N}=32, \mathrm{w}=168, p=0.158)$.
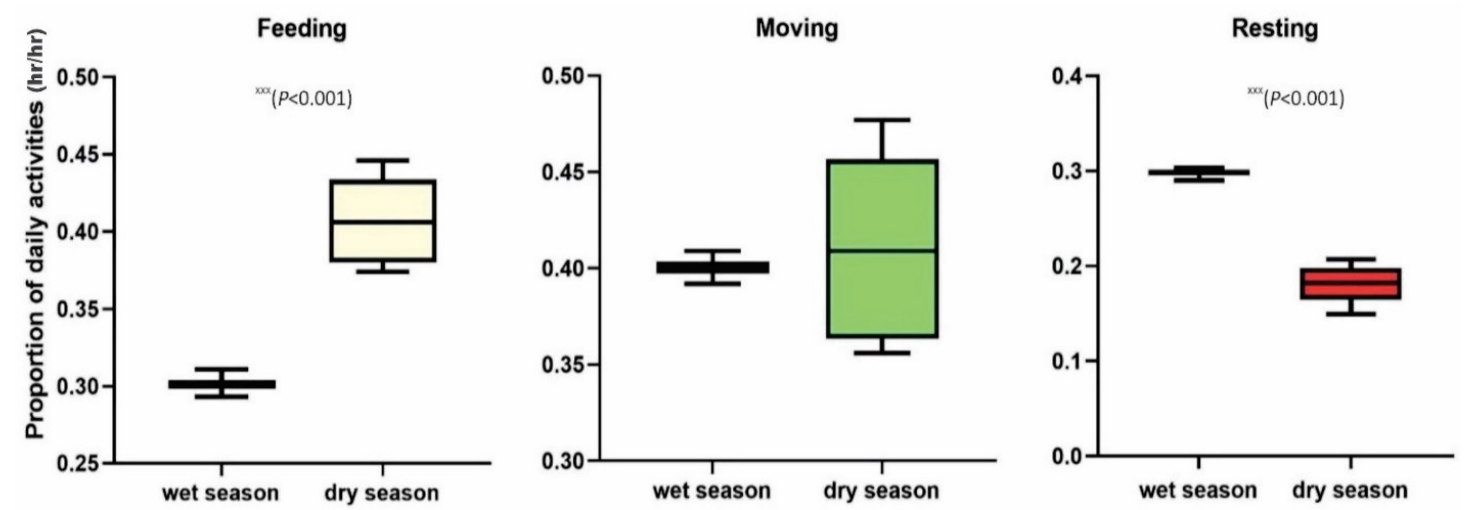

\section{Seasons}

Figure 2. Proportion of daily activities spent by Lowe's monkeys feeding $(p=0.0001)$, moving $(p=0.158)$, and resting $(p=0.0001)$ during the dry and wet seasons in the Duasidan monkey sanctuary, Ghana ( $\left.{ }^{x x x} p<0.001\right)$. The line in the boxes represents a median value while the boxes represent interquartile ranges and whiskers represent the range of minimum and maximum values. 


\subsection{Food Categories}

In both wet and dry seasons, plants (64.3\% and $57.8 \%$, respectively) constituted the highest proportion of food items consumed by Lowe's monkeys, followed by anthropogenic food (34.8\% and $41.3 \%)$ and then invertebrates $(0.9 \%$ each, Figure 3$)$. We found no significant differences in the diet composition between the wet and dry seasons (Wilcoxon rank sum test: $\mathrm{N}=32, \mathrm{w}=87.5, p=0.129$, anthropogenic food: $\mathrm{N}=32, \mathrm{w}=171, p=0.107$, invertebrate: $\mathrm{N}=32, \mathrm{w}=128.5, p=1.000$ ).
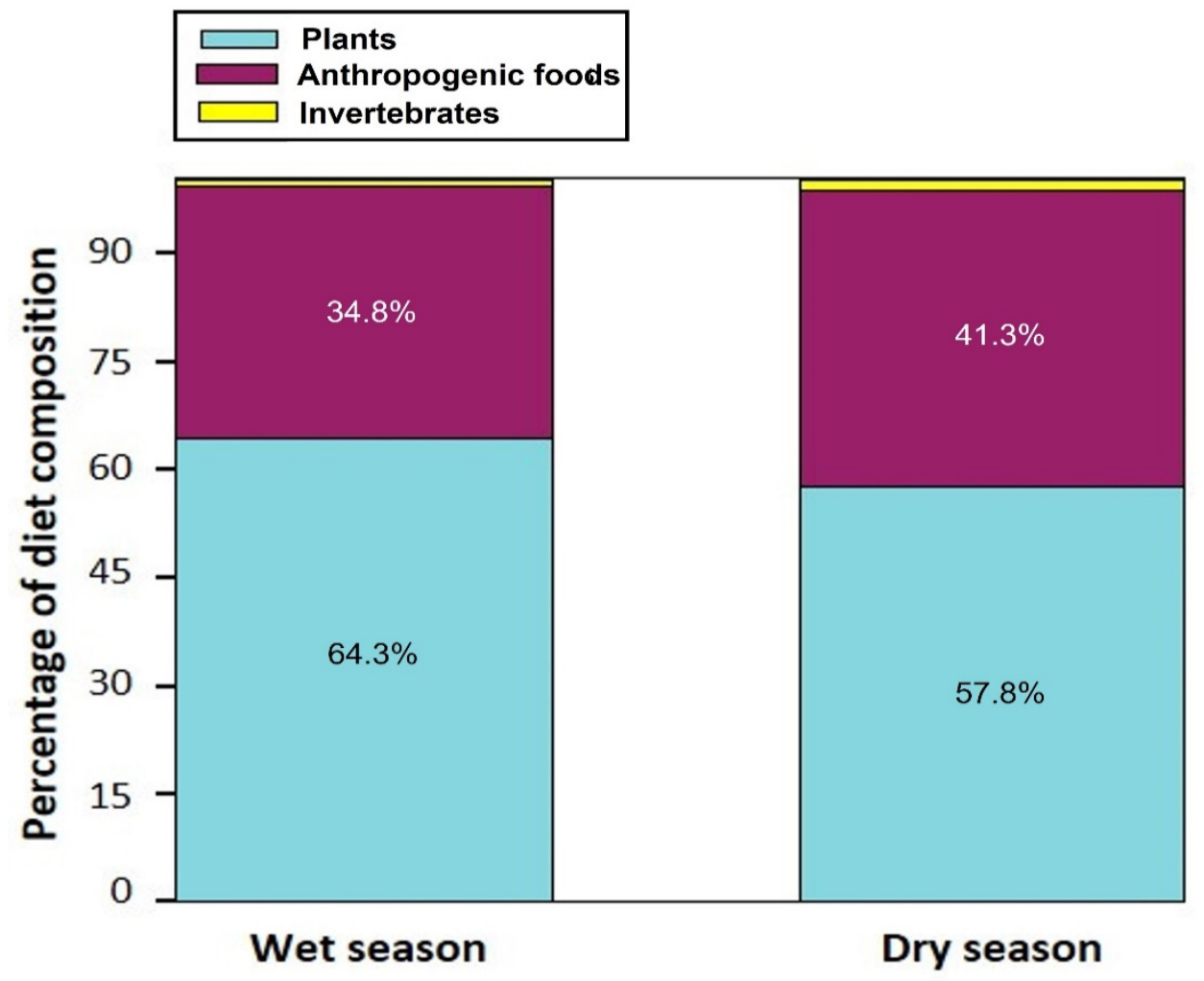

Figure 3. Percentage composition of plant, anthropogenic food, and invertebrates in the diet of Lowe's monkeys in the wet and dry seasons at Duasidan Monkey Sanctuary, Ghana (Wilcoxon rank sum test: $p>0.05)$.

\subsubsection{Plants Consumed}

We identified 24 plant species belonging to 17 different families from the study area. We observed that Lowe's monkeys consumed 13 plant species in the dry season and eight plant species in the wet season (Table 1). There was a significant difference in fruits and buds consumed by the monkeys between wet and dry seasons (both $\mathrm{N}=32$, fruits; $\mathrm{w}=23.5$, $p<0.001$, buds; $\mathrm{w}=236.5, p<0.001)$ but a no-significant difference in seeds $(\mathrm{N}=32, \mathrm{w}=114$, $p=0.455)$, leaves $(\mathrm{N}=32, \mathrm{w}=153, p=0.298)$, and flowers $(\mathrm{N}=32, \mathrm{w}=120.5, p=0.602)$ between wet and dry seasons. The proportion of fruits consumed by the monkeys was higher in the wet season than the dry season $(71.2 \pm 3.3 \%)$, while the proportion of buds was higher in the dry season than the wet season (44.8 $\pm 3.9 \%$; Figure 4$)$. 
Table 1. Preference indices of plant species consumed by Lowe's monkeys in the Duasidan Monkey Sanctuary, Ghana.

\begin{tabular}{lcccc}
\hline \multicolumn{1}{c}{ Species } & $\begin{array}{c}\text { Dry Season } \\
\text { Number of Feeding } \\
\text { Observations }\end{array}$ & $\begin{array}{c}\text { Preference } \\
\text { Indices }\end{array}$ & $\begin{array}{c}\text { Wumber of Feeding } \\
\text { Observations }\end{array}$ & Preference Indices \\
\hline Bombax buonopozense & 2 & $0.39^{*}$ & - & - \\
Ceiba pentandra & 8 & $0.78^{*}$ & 13 & $1.26^{*}$ \\
Celtis milbraedii & 3 & $0.84^{*}$ & - & - \\
Cola gigantean & 5 & $2.44^{* *}$ & $-19^{*}$ & - \\
Dacryodes klaineana & 1 & $1.56^{*}$ & $3.42^{* *}$ \\
Discoglypremna caloneura & 4 & $3.13^{* *}$ & 14 & - \\
Ficus exasperata & 8 & $2.27^{* *}$ & 6 & $1.17^{*}$ \\
Mangnifera indica & 7 & $0.97^{*}$ & 2 & $5.47^{* * *}$ \\
Milicia excelsa & 3 & $1.95^{* *}$ & 15 & $1.95^{* *}$ \\
Pycnanthus angolensis & 10 & $1.75^{*}$ & 12 & $0.65^{*}$ \\
Raphia hookeri & 9 & $0.39^{*}$ & - & $2.92^{* *}$ \\
Spondias mombin & 1 & $0.19^{*}$ & - & $2.34^{* *}$ \\
Terminalia ivorensis & 2 & - & - \\
\hline
\end{tabular}

Diet preference: * low preference; ${ }^{* *}$ average preference; ${ }^{* * *}$ high preference.

During the wet season, Ficus exasperata was the most preferred food item, with a preference index of 5.47, followed by Cola gigantean (3.42), Pycnanthus angolensis (2.92), and Raphia hookeri (2.37). During the dry season, F. exasperata was the still most preferred plant species, with a preference index of 3.13, followed by C. gigantean (2.44) and Mangnifera indica (2.27; Table 1). We found different diversity indices of plant species consumed by the monkeys for wet (Shannon-Wiener diversity index: $H=1.92$ ) and dry seasons (Shannon-Wiener diversity index: $\mathrm{H}^{1}=2.35$ ), with a higher diversity in the dry season.

\section{Fruits}

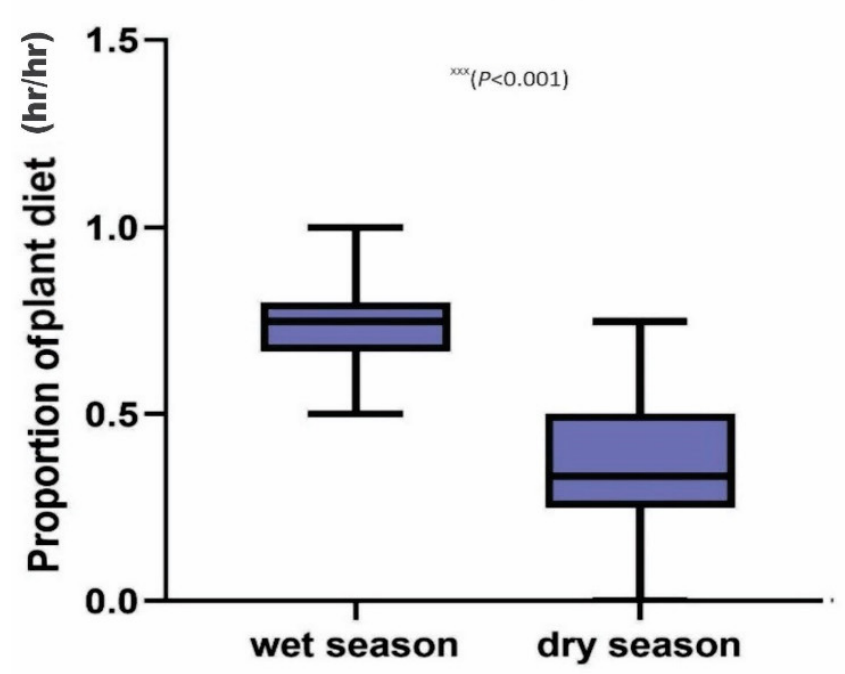

\section{Buds}

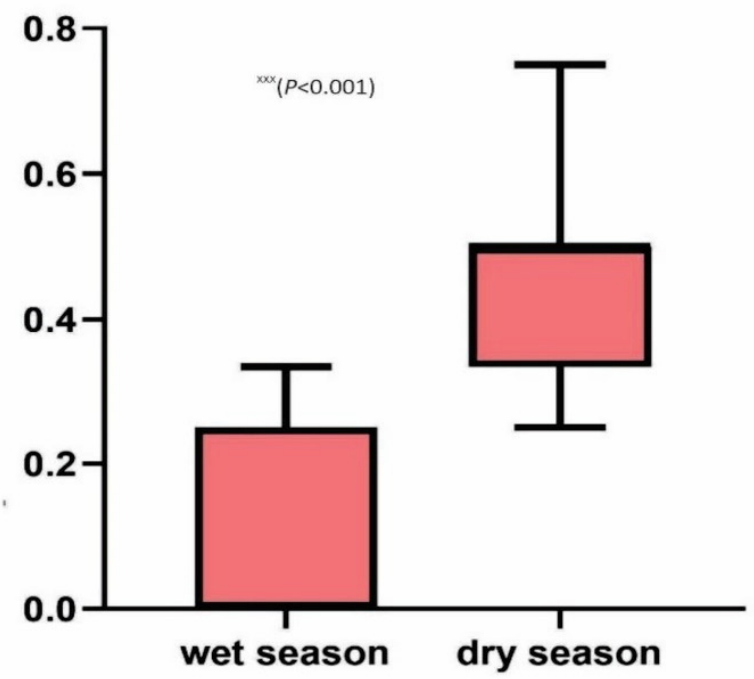

\section{Seasons}

Figure 4. Proportion of fruit $(p<0.001)$ and buds $(p<0.001)$ consumed by Lowe's monkeys in wet and dry seasons in the Duasidan Monkey Sanctuary, Ghana ( $\left.{ }^{x x} p<0.001\right)$. The line in the boxes represents a median value while the boxes represent interquartile ranges and whiskers represent the range of minimum and maximum values.

\subsubsection{Anthropogenic Food Type Consumed}

Lowe's monkeys retrieved anthropogenic food by processing non-segregated anthropogenic foods at the dumpsites. Among the anthropogenic food types, leftover foods 
(39.9\%) constituted the highest proportion of the Lowe's monkeys' diet in the wet season, while uncooked food/peels $(50.5 \%)$ constituted the highest proportion in the dry season. There were no significant differences in the proportion of anthropogenic foods consumed by Lowe's monkeys between wet and dry seasons for uncooked food/peels $(\mathrm{N}=32, \mathrm{w}=157, p=0.274)$, leftover foods $(\mathrm{N}=32, \mathrm{w}=113.5, p=0.589)$, and food in a plastic cover $(\mathrm{N}=32, \mathrm{w}=126.5, p=0.968)$.

\section{Discussion}

Lowe's monkeys at the Duasidan Monkey Sanctuary (DMS) seasonally altered their diet on plant parts while exhibiting seasonally stable feeding behaviors utilizing anthropogenic foods. Regarding the plant types, the monkeys consumed more fruits than other plant parts during the wet than the dry season, and more buds in the dry than the wet season. Lowe's monkeys spent more time to consume plant species and less anthropogenic food in the wet season than the dry season; however, the monkeys fed considerably often on anthropogenic food throughout the seasons, differing from our prediction. Our results suggest that (1) Lowe's monkeys seasonally adjust their diet on plant parts, probably according to nutrient content and availability, and (2) anthropogenic food has an important role in Lowe's monkeys' diet throughout the seasons.

The amount of time Lowe's monkeys spent feeding increased in the dry season. The seasonal variation in the activity budget of Lowe's monkeys is probably because of the low food availability season [29,30]; for instance, the animals spent more time foraging to compensate for the low quality of foods in the dry season $[28,29]$. This may maximize energy intake and helps to meet their daily nutrient requirements $[21,36]$. The Lowe's monkeys rested significantly more during the wet season. This result might indicate that the monkeys do not need to spend as much time foraging since food resources become more abundant during the wet season. This suggests that the activity budget of primates that feed on anthropogenic food may be altered seasonally [6,8]. Anthropogenic foods also can affect feeding time; for example, Cercopithecus aethiops (African green monkey) that feed on wild plants spend $40 \%$ of their time feeding compared with $20 \%$ for individuals of the same species that feed on anthropogenic foods [37]. Similarly, Papio anubis (Olive baboon) and Macaca mulatta (Rhesus macaque) spend 25\% and 50\% feeding on anthropogenic food but less than $17 \%$ and $27 \%$, respectively, feeding on wild foods [38,39].

Our results regarding the seasonal change in Lowe's monkeys' plant diet suggest that other plant parts can have an important role when fruit availability is low. For example, buds are known to have high water content [40] and chemical elements such as ascorbic acid [41], which may help the Lowe's monkeys to fulfill their dietary requirement, especially during the dry season. Our results also suggest that buds can be fallback food for the monkeys, similarly to the results from other studies [42-44]. When it comes to preferences, Lowe's monkeys did not have a seasonal preference on plants. This might be because the preferred plants of Lowe's monkeys at the Duasidan Monkey Sanctuary produce different consumable parts at different periods of the year. For example, Raphia hookeri produces different parts including fruits and leaves in the wet and dry seasons [45-48]. Plants that primates feed on often have different parts readily available and in sufficient quantity throughout the year $[33,34,49]$. This was most evident in our study, revealing that the Lowe's monkeys highly consumed Anacardiaceae, Moraceae, and Bombaceae species, most of which produce plant parts available for several months of the year covering both dry and wet seasons. Moreover, the plant species preferred in both seasons by the Lowe's monkeys might have high nutrition, especially Ficus exasperata, Cola gigantean, $R$. hookeri, Pycnanthus angolensis, and Mangnifera indica, as shown in other studies [50,51].

The impact of anthropogenic food on wild animals is gaining attention by conservationists worldwide [52]. Several studies confirmed that primates spend large amounts of their feeding time consuming anthropogenic food [6,9]. For example, Cebus libidinosus (Capuchin monkeys) spend 38\% of their feeding time on anthropogenic foods [50] and Papio sp. spend 25\% [33,38] and 20\% [6] of their feeding time on anthropogenic foods. 
We found that Lowe's monkeys fed on anthropogenic food in both wet and dry seasons, indicating that the species consumes anthropogenic food all year round. Our results indicate that anthropogenic food is not serving as fallback food for the period with low fruit availability, but as a stable food resource for the Lowe's monkeys. Similar to our study, Sabbatini et al. [53] found that capuchin monkeys constantly consume food they obtained from the garbage. However, Macdonald et al. [54] suggested that the presence of anthropogenic food in the diet of animals could be because of a lack of naturally occurring foods.

Many factors may regulate the consumption of anthropogenic foods, including fewer efforts in processing and digesting food items as well as high nutritional value $[9,55]$. The anthropogenic food sources are highly likely to provide nutrition gains to the monkeys [21,23]. Furthermore, the monkeys inspected (i.e., handling and smelling) substances before eating and they sometimes rejected a substance after inspection, indicating that they were probably able to distinguish between perished and still edible foods and waste. Wild Rhesus monkeys (Macaca mulatta) were found to adopt a similar strategy when feeding on garbage to avoid the risk of ingesting plastic [36]. Thus, the Lowe's monkeys may have a similar strategy when selecting anthropogenic food

Despite the potential benefits of anthropogenic food to wild primates, a principal concern regarding anthropogenic food intake is the alteration of their behaviors and health condition due to nutritional values and contamination [55]. For instance, the activity budget of primates that feed on anthropogenic food is mostly altered, with minimum time spent feeding and more time resting [6,8]. There is a direct relationship between an animal's activity budget and its bioenergetic allocation. Any changes in the activity budget can negatively affect bioenergetic allocations of the animal. This could result in reduced abilities of the individuals to survive and reproduce $[56,57]$. Managing garbage as a food supplementation tool has been discussed for many decades [58]. The two opposing ends are either to control wildlife feeding on garbage or stop wildlife from utilizing garbage dumps. The general current consensus is to restrict access; for example, officials of the Yellowstone National Park in the 1970s closed all dumps to eradicate the provision of anthropogenic food to bears in and around the National Park [59]. Here, we would like to emphasize the comparatively high volume of anthropogenic food as a food source of the Lowe's monkey. However, if access to anthropogenic foods is not restricted, in the future, an unequal access to foods at the garbage site could result in competition within or among the groups and potentially affect the good health and robustness of the individuals in the group [55]. Limited access to such foods could also cause monkeys to troop to the homes of people, resulting in conflict, although we have not yet observed any direct conflict between the Lowe's monkeys and local people at the Duasidan Monkey Sanctuary, in opposition to the study conducted in Boabeng-Fiema Monkey Sanctuary [60]. This suggests that abruptly removing the access to garbage dumps might have a short- to medium-term abrupt negative effect on the monkeys, given their reliance on the anthropogenic foods. While proper management of the garbage would allow the monkeys to take advantage of anthropogenic foods, a long-term plan for gradual reduction of the human-mediated foods and preventing monkeys' habitat degradation will be required for the species' conservation. The traditional authorities of the Duasidan community are recommended to liaise with the Wildlife Division of Ghana, the technical department responsible for wildlife conservation in Ghana, and also engage non-governmental organization (NGOs) to develop a sustainable management plan for the monkey sanctuary. Even though our study area covers a relatively small area, its conservation is of valuable importance as it is one of the few areas in Ghana to harbor the remaining populations of Lowe's monkeys.

Author Contributions: Conceptualization, G.B.; methodology, G.B.; formal analysis, G.B. and Y.Y.; data curation, G.B.; writing—original draft preparation, G.B.; writing-review and editing, G.B., C.L. and Y.Y. All authors have read and agreed to the published version of the manuscript.

Funding: This research received no external funding. 
Institutional Review Board Statement: The Wildlife Department of the Resource Management Support Centre/Forestry Commission of Ghana reviewed sampling procedures and gave approval for the research.

Data Availability Statement: The data used are available from the author upon request.

Acknowledgments: The authors would like to thank the people of Duasidan community, especially the elders and management of the Duasidan Monkey Sanctuary for the assistance offered during the data collection. We also like to thank Christian A. Fumey-Nassah for sharing with us technical information about the study area. We are grateful to Edward Debrah Wiafe for providing a picture of the species in the study site. This study was supported by the Basic Science Research Program through the National Research Foundation of Korea (NRF) funded by (2021R1A6A3A03039709) and National Natural Science Foundation of China (31870506).

Conflicts of Interest: The authors declare no conflict of interest.

\section{References}

1. White, T.C.R. The importance of a relative shortage of food in animal ecology. Oecologia 1978, 33, 71-86. [CrossRef]

2. Hill, D.A. Seasonal variation in the feeding behavior and diet of Japanese macaques (Macaca fuscata yakui) in lowland forest of Yakushima. Am. J. Primatol. 1997, 43, 305-320. [CrossRef]

3. Stone, A.I. Responses of squirrel monkeys to seasonal changes in food availability in an eastern Amazonian Forest. Am. J. Primatol. 2007, 69, 142-157. [CrossRef] [PubMed]

4. Bateman, P.W.; Fleming, P.A. Big city life: Carnivores in urban environments. J. Zool. 2012, 287, 1-23. [CrossRef]

5. McKinney, T. A classification system for describing anthropogenic influence on nonhuman primate populations. Am. J. Primatol. 2015, 77, 715-726. [CrossRef] [PubMed]

6. Altmann, J.; Muruthi, P. Differences in daily life between semiprovisioned and wild-feeding baboons. Am. J. Primatol. 1988, 15, 213-221. [CrossRef] [PubMed]

7. McLennan, M.R.; Spagnoletti, N.; Hockings, K. The Implications of Primate Behavioral Flexibility for Sustainable Human-Primate Coexistence in Anthropogenic Habitats. Int. J. Primatol. 2017, 38, 105-121. [CrossRef]

8. Sengupta, A.; McConkey, K.R.; Radhakrishna, S. Primates, Provisioning and Plants: Impacts of Human Cultural Behaviours on Primate Ecological Functions. PLoS ONE 2015, 10, e0140961. [CrossRef] [PubMed]

9. McKinney, T. The effects of provisioning and crop-raiding on the diet and foraging activities of human-commensal white-faced Capuchins (Cebus capucinus). Am. J. Primatol. 2010, 73, 439-448. [CrossRef]

10. Lawson, B.; Robinson, R.A.; Toms, M.P.; Risely, K.; Macdonald, S.; Cunningham, A.A. Health hazards to wild birds and risk factors associated with anthropogenic food provisioning. Philos. Trans. R. Soc. B Biol. Sci. 2018, 373, 20170091. [CrossRef]

11. Plaza, P.I.; Lambertucci, S.A. How are garbage dumps impacting vertebrate demography, health, and conservation? Glob. Ecol. Conserv. 2017, 12, 9-20. [CrossRef]

12. Baulu, J.; Everard, C.O.R.; Everard, J.D. Leptospires in vervet monkeys (Cercopithecus aethiops sabaeus) on barbados. J. Wildl. Dis. 1987, 23, 60-66. [CrossRef]

13. Erdozain, G.; KuKanich, K.; Chapman, B.; Powell, D. Best Practices for Planning Events Encouraging Human-Animal Interactions. Zoonoses Public Health 2014, 62, 90-99. [CrossRef]

14. Rogers, L.L. Black Bears, People, and Garbage Dumps in Minnesota. In Bearhuman Conflicts: Proceedings of a Symposium on Management Strategies; Bromley, M., Ed.; Northwest Territories Department of Renewable Resources, 1989; Available online: http:/ / www.bearsmart.com/docs/Black_Bears_People_and_Garbarge_Dumps_in_Minnesota.pdf (accessed on 5 January 2020).

15. Houston, D.C.; Mee, A.; McGrady, M. Why do condors and vultures eat junk? The implications for conservation. J. Raptor Res. 2007, 41, 235-238. [CrossRef]

16. Saj, T.; Sicotte, P.; Paterson, J.D. Influence of Human Food Consumption on the Time Budget of Vervets. Int. J. Primatol. 1999, 20, 977-994. [CrossRef]

17. Bino, G.; Dolev, A.; Yosha, D.; Guter, A.; King, R.; Saltz, D.; Kark, S. Abrupt spatial and numerical responses of overabundant foxes to a reduction in anthropogenic resources. J. Appl. Ecol. 2010, 47, 1262-1271. [CrossRef]

18. Chamberlain, D.E.; Vickery, J.A.; Glue, D.E.; Robinson, R.A.; Conway, G.J.; Woodburn, R.J.W.; Cannon, A.R. Annual and seasonal trends in the use of garden feeders by birds in winter. Ibis 2005, 147, 563-575. [CrossRef]

19. Higham, J.P.; Warren, Y.; Adanu, J.; Umaru, B.N.; MacLarnon, A.M.; Sommer, V.; Ross, C. Living on the edge: Life-history of olive baboons at Gashaka-Gumti National Park, Nigeria. Am. J. Primatol. 2009, 71, 293-304. [CrossRef]

20. Strum, S.C. The Development of Primate Raiding: Implications for Management and Conservation. Int. J. Primatol. 2010, 31, 133-156. [CrossRef] [PubMed]

21. Rogers, L.L. Effects of Food Supply and Kinship on Social Behavior, Movements, and Population Growth of Black Bears in Northeastern Minnesota. Wildl. Monogr. 1987, pp. 3-72. Available online: https://www.jstor.org/stable/3830545 (accessed on 5 January 2020). 
22. Stillfried, M.; Gras, P.; Busch, M.; Börner, K.; Kramer-Schadt, S.; Ortmann, S. Wild inside: Urban wild boar select natural, not anthropogenic food resources. PLoS ONE 2017, 12, e0175127. [CrossRef] [PubMed]

23. Rogers, L.L.; Kuehn, D.W.; Erickson, A.W.; Harger, E.M.; Verme, L.J.; Ozoga, J.J. Characteristics and management of black bears that feed in garbage dumps, campgrounds or residential areas. Bears Biol. Manag. 1976, 3, 169-175. [CrossRef]

24. Wiafe, E.; Oates, J.F.; Gonedelé Bi, S.; Koné, I.; Matsuda Goodwin, R.; Osei, D. Cercopithecus lowei, The IUCN Red List of Threatened Species 2019: e.T136931A92373680. Available online: https:/ / dx.doi.org/10.2305/IUCN.UK.2019-1.RLTS.T136931A92373680.en (accessed on 27 September 2021).

25. Bourliere, F.; Hunkeler, C.; Bertrand, M. Ecology and behaviour of Lowe's Guenon (Cercopithecus lowei) in Ivory Coast. In Old World Monkeys: Evolution, Systemaics and Behaviour; Napier, J.R., Napier, P.H., Eds.; Academic Press: London, UK, 1970; pp. 297-350.

26. Kingdon, J. The Kingdon Field Guide to African Mammals; Academic Press: London, UK, 1997.

27. Wiafe, E.D. Population studies of Lowe's monkeys (Cercopithecus lowei Thomas, 1923) in Kakum Conservation Area, Ghana. J. Threat. Taxa 2016, 8, 8434-8442. [CrossRef]

28. Barrett, L.; Dunbar, R.I.; Dunbar, P. Environmental influences on play behaviour in immature gelada baboons. Anim. Behav. 1992, 44, 111-115. [CrossRef]

29. Norscia, I.; Carrai, V.; Borgognini-Tarli, S.M. Influence of Dry Season and Food Quality and Quantity on Behavior and Feeding Strategy of Propithecus verreauxi in Kirindy, Madagascar. Int. J. Primatol. 2006, 27, 1001-1022. [CrossRef]

30. Biodiversity Monitoring Unit: Biodiversity Monitoring at Duasidan Monkey Sanctuary; Wildlife Division, Forestry Commission: Accra, Ghana, 2002.

31. Sillero-Zubiri, C.; Switzer, D. Crop Raiding Primates: Searching for Alternative, Humane Ways to Resolve Conflict with Farmers in Africa; Wildlife Conservation Research Unit, Oxford University: Oxford, UK, 2001.

32. Olaleru, F.; Ogunjemite, B.G.; Onadeko, A.B.; Egonmwan, R.I. Seasonal Availability and Nutrient Contents of Mona Monkey (Cercopithecus mona Schreber, 1774) Plant Diets in Lekki Conservation Centre, Nigeria. Munis Entomol. Zool. 2018, 13, 574-582. Available online: https:/ / www.researchgate.net/publication/325880916 (accessed on 5 January 2020).

33. Ejidike, B.N.; Salawu, A. Food and Feeding Habits of Mona Monkey Cercopithecus Mona in Ayede/Isan Forest Reserve, Ekiti State. Journal of Research in Forestry. Wildl. Environ. 2009, 1, 56-59.

34. Mangama-Koumba, L.B.; Ella, G.W.E.; Akomo-Okoue, E.F.; Nguelet, F.L.M.; M’Batchi, B.; Mavoungou, J.F. Vegetarian diet in Guenon and Mangabey monkeys of Moukalaba-Doudou National Park, Gabon: Similarities and differences. Int. J. Biol. Chem. Sci. 2017, 10, 2435. [CrossRef]

35. Ejidike, B.N.; Okosodo, E.F. Food and feeding habits of the thicktailed galago (Otelemur crassicaudatus) in Okomu National Park, Edo state. J. Fish. Int. 2007, 2, 231-233.

36. Katlam, G.; Prasad, S.; Aggarwal, M.; Kumar, R. Trash on the menu: Patterns of animal visitation and foraging behaviour at garbage dumps. Curr. Sci. 2018, 115, 2322-2326. [CrossRef]

37. Lee, P.C.; Brennan, E.J.; Else, J.G.; Altmann, J. Ecology and behavior of vervet monkeys in a tourist lodge habitat. In Primate Ecology and Conservation; Else, J.G., Lee, P.C., Eds.; Cambridge University Press: Cambridge, UK, 1986; pp. $229-235$.

38. Masau, J.M.; Strum, S.C. Response of wild baboon troops to incursion of agriculture at Gilgil, Kenya. Int. J. Primatol. 1984, 5, 364.

39. Malik, I. Time budgets and activity patterns in free-ranging rhesus monkeys. In Primate Ecology and Conservation; Else, J.G., Lee, P.C., Eds.; Cambridge University Press: Cambrdige, UK, 1986; pp. 105-114.

40. Pharis, R.P. Seasonal fluctuation in the foliage-moisture content of well-watered conifers. Bot. Gaz. 1967, 128, 179-185. [CrossRef]

41. Milton, K. Micronutrient intakes of wild primates: Are humans different? Comp. Biochem. Physiol. Part A Mol. Integr. Physiol. 2003, 136, 47-59. [CrossRef]

42. Grueter, C.C.; Li, D.; Ren, B.; Wei, F.; Xiang, Z.; van Schaik, C.P. Fallback foods of temperate-living primates: A case study on snub-nosed monkeys. Am. J. Phys. Anthr. 2009, 140, 700-715. [CrossRef] [PubMed]

43. Hanya, G.; Bernard, H. Fallback Foods of Red Leaf Monkeys (Presbytis rubicunda) in Danum Valley, Borneo. Int. J. Primatol. 2012, 33, 322-337. [CrossRef]

44. Poulsen, J.R.; Clark, C.J.; Smith, T.B. Seasonal variation in the feeding ecology of the grey-cheeked mangabey (Lophocebus albigena) in Cameroon. Am. J. Primatol. 2001, 54, 91-105. [CrossRef] [PubMed]

45. Ndon, B.A. Some Morphological and Chemical Characteristics of Developing Fruits of Raphia hookeri. J. Exp. Bot. 1985, 36, 1817-1830. [CrossRef]

46. Oluyori, A.; Dada, A.O.; Inyinbor, A. Phytochemical Analysis and Antioxidant Potential of Raphia hookeri leaf and Epicarp. Orient. J. Chem. 2018, 34, 2742-2746.

47. Profizi, J.P. Swampy area transformations by exploitation of Raphia hookeri (Arecaceae) in southern Benin (West Africa). Hum. Ecol. 1988, 16, 87-94. [CrossRef]

48. Udofia, S.I.; Oworen, U.I. Conservation status of Raphia hookeri Mann \& Wendil in homegardens of Ika Local Government Area, Akwa Ibom State, Nigeria. Niger. J. Agric. Food Environ. 2018, 13, 170-175.

49. Takenoshita, Y.; Ando, C.; Yamagiwa, J. Fruit phenology of the great ape habitat in the Moukalaba-Doudou National Park, Gabon. Afr. Study Monogr. 2008, 39, 23-39. [CrossRef]

50. Bello, M.O.; Abdul-Hammed, M.; Ogunbeku, P. Nutrient and anti-nutrient phytochemicals in Ficus exasperata Vahl leaves. Int. J. Sci. Eng. Res. (IJSER) 2014, 5, 2177-2181. 
51. Bello, M.O.; Abdul-Hammed, M.; Adepoju, A.J.; Esan, O.A.; Tiamiyu, A.A. Nutritional Composition and fatty acids profile of Ficus exasperata fruit and fruit oil. J. Nat. Sci. Res. 2014, 4, 25-29.

52. Oro, D.; Genovart, M.; Tavecchia, G.; Fowler, M.S.; Martínez-Abraín, A. Ecological and evolutionary implications of food subsidies from humans. Ecol. Lett. 2013, 16, 1501-1514. [CrossRef] [PubMed]

53. Sabbatini, G.; Stammati, M.; Tavares, M.C.H.; Giuliani, M.V.; Visalberghi, E. Interactions between humans and capuchin monkeys (Cebus libidinosus) in the Parque Nacional de Brasília, Brazil. Appl. Anim. Behav. Sci. 2006, 97, 272-283. [CrossRef]

54. Macdonald, D.W.; Boitani, L.; Barrasso, P. Foxes, wolves and conservation in the Abruzzo mountains. In The Red Fox; Springer: Dordrecht, The Netherlands, 1980; pp. 223-235. [CrossRef]

55. Marty, P.R.; Balasubramaniam, K.N.; Kaburu, S.S.K.; Hubbard, J.; Beisner, B.; Bliss-Moreau, E.; Ruppert, N.; Arlet, M.E.; Sah, S.A.M.; Ismail, A.; et al. Individuals in urban dwelling primate species face unequal benefits associated with living in an anthropogenic environment. Primates 2019, 61, 249-255. [CrossRef] [PubMed]

56. Christiansen, F.; Rasmussen, M.H.; Lusseau, D. Inferring activity budgets in wild animals to estimate the consequences of disturbances. Behav. Ecol. 2013, 24, 1415-1425. [CrossRef]

57. Bejder, L. Linking Short and Long-Term Effects of Nature-Based Tourism on Cetaceans. Ph.D. Dissertation, Dalhousie University, Halifax, NS, Canada, 2005.

58. Martina, A.; Gallarati, M. Use of a Garbage Dump by Some Mammal Species in the Majella Massif (Abruzzo, Italy). Hystrix Ital. J. Mammal. 1997, 9, pp. 1-2. Available online: http:/ / citeseerx.ist.psu.edu/viewdoc/download?doi=10.1.1.616.190 8andrep=replandtype (accessed on 5 January 2020).

59. Conniff, R. Unnatural Balance: How Food Waste Impacts World's Wildlife. Yale Environ. 2016. Yale Environment 360. Available online: https: / /e360.yale.edu/features/unnatural_balance_how_food_waste_impacts_world (accessed on 15 April 2020).

60. Wiafe, E.D.; Arku, F.S. Victims' Perspectives of Lowe's Monkeys' (Cercopithecus campbelli lowei) crop raiding events in Ghana: A case of Boabeng-Fiema Monkey Sanctuary. J. Biodivers. Environ. Sci. 2012, 2, 1-8. 